\title{
Macular Cystoid Edema Induced by Nab-Paclitaxel
}

\section{Edema Macular Cistóide Secundário ao Nab-Paclitaxel}

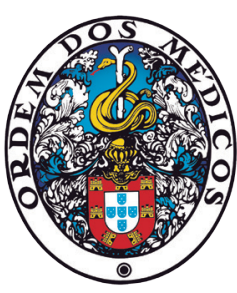

Sara ALVES PEREIRA $\triangle^{1}$, Carolina VALE ${ }^{1}$, Jorge MOREIRA ${ }^{1}$, Filipa SAMPAIO ${ }^{1}$

Acta Med Port 2022 Apr;35(4):294-297 • https://doi.org/10.20344/amp.13421

\section{ABSTRACT}

A 61-year old male was referred to the Ophthalmology department because of decreased bilateral visual acuity. The patient had metastatic pancreatic adenocarcinoma and was being treated with gemcitabine+nab-paclitaxel. On examination, the patient presented best corrected visual acuities of $4 / 20$ and $2 / 20$ in the right and left eye, respectively. The optical coherence tomography revealed bilateral severe macular edema. Macular edema was considered secondary to nab-paclitaxel and the drug was discontinued. Three months after drug discontinuation, the patient presented best corrected visual acuities of 20/20 and 16/20 in the right and left eye, respectively, and normal fundoscopy. Macular edema is a very rare side effect of taxanes, and the etiopathology is still unknown. Edema is usually reversible upon discontinuation of the offending agent. Clinicians should be aware of this adverse effect of taxanes, and a high index of clinical suspicion is essential for diagnosis.

Keywords: Albumins/adverse effects; Albumin-Bound Paclitaxel/adverse effects; Macular Edema/chemically induced; Paclitaxel/adverse effects; Pancreatic Neoplasms/drug therapy

\section{RESUMO}

Doente do sexo masculino, de 61 anos de idade, foi encaminhado para Oftalmologia por queixas de diminuição da acuidade visual bilateral. Tratava-se de um doente com um adenocarcinoma pancreático metastizado, sob tratamento com gemcitabina+nab-paclitaxel. Ao exame oftalmológico, o doente apresentava melhores acuidades visuais corrigidas de 4/20 e 2/20 do olho direito e esquerdo, respetivamente. A tomografia de coerência ótica revelou a presença de edema macular bilateral grave. O edema macular foi considerado secundário ao uso de nab-paclitaxel, pelo que o fármaco foi suspenso. Três meses após a suspensão do fármaco, o paciente apresentava acuidades visuais de $20 / 20$ e 16/20 do olho direito e esquerdo, respetivamente, e uma fundoscopia normal. O edema macular é um efeito adverso muito raro dos taxanos e a sua etiopatologia ainda não se encontra totalmente esclarecida. O edema é habitualmente reversível após a suspensão do agente causador. Um elevado índice de suspeição é essencial para o diagnóstico desta condição. Palavras-chave: Albuminas/efeitos adversos; Edema Macular/induzido quimicamente; Neoplasias Pancreáticas/tratamento farmacológico; Paclitaxel/efeitos adversos; Paclitaxel Ligado a Albumina/efeitos adversos

\section{INTRODUCTION}

Taxanes are a group of chemotherapeutic agents that inhibit cell division by causing stabilization of cellular microtubules. Agents in this group include paclitaxel (a natural compound extracted from the yew tree), docetaxel (a semisynthetic analog) and nanoparticle albumin-bound (nab)paclitaxel (better bioavailability and tolerability than paclitaxel)..$^{1,2}$

Taxanes are approved for the treatment of breast, ovarian and lung cancer, but they are also used off-label in several other malignancies (e.g. endometrial, gastroesophageal, prostate, among others). ${ }^{1}$ Nab-paclitaxel combined with gemcitabine has been recently advocated as a standard treatment option for metastatic pancreatic cancer. ${ }^{2,3}$

Common associated side effects of taxane therapy include neuropathy and hypersensitivity reactions. ${ }^{4,5}$ Macular edema is a very rare side effect and its etiopathology is still misunderstood. ${ }^{6}$

\section{CASE REPORT}

A 61-year-old male presented with a history of bilateral and progressive vision loss in the previous month. The patient had a diagnosis of metastatic pancreatic cancer diagnosed five months before and had been treated with gem- citabine and albumin protein bound paclitaxel (nab-paclitaxel). He was also taking a proton-pump inhibitor, gabapentin and tapentadol for chronic pain. The remaining past medical history, including ophthalmic history, was irrelevant.

Upon examination, best corrected visual acuities were $4 / 20$ and $2 / 20$ in the right and left eye, respectively. The anterior segment examination was unremarkable, but fundoscopy showed an altered foveal reflex present bilaterally. The spectral-domain optical coherence tomography (SD-OCT) revealed a thickened retina with multiple intraretinal hyporeflective cystic spaces, mainly affecting the outer plexiform layer, suggestive of cystoid macular edema. A small foveal area of subretinal fluid coexisted in the left eye. The central retinal thickness (CRT) was 671 and $582 \mu \mathrm{m}$, in the right and left eye, respectively (Fig. 1). No other lesions or changes were evident on fundoscopy or optical coherence tomography (OCT).

Fluorescein angiography was not performed given the patient's general health status and the high clinical suspicion of taxane-related maculopathy. Follow-up was performed with OCT only.

Nab-paclitaxel was discontinued, and chemotherapy was altered to gemcitabine + capecitabine. The patient

\footnotetext{
1. Departamento de Oftalmologia. Unidade Local de Saúde Matosinhos. Senhora da Hora. Portugal.

$\triangle$ Autor correspondente: Sara Alves Pereira. salves gp@hotmail.com

Recebido/Received: 11/01/2020 - Aceite/Accepted: 30/07/2020 - Publicado Online/Published Online: 21/07/2021 - Publicado/Published: 01/04/2022 Copyright $\odot$ Ordem dos Médicos 2022
} 

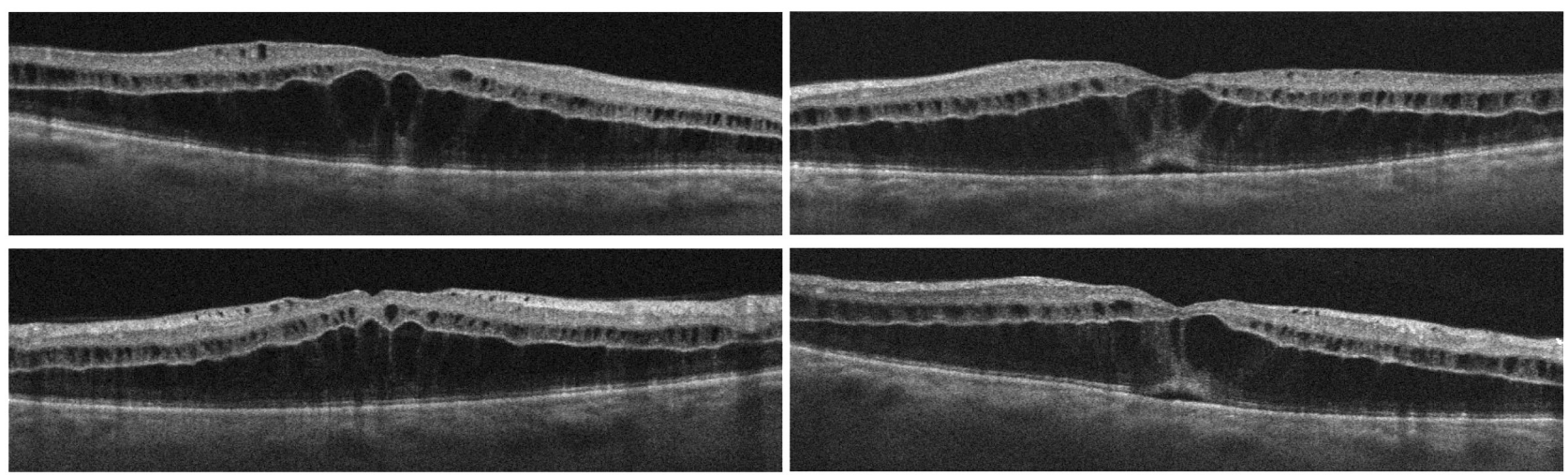

Figure 1 - OCT revealing severe cystoid macular edema of the right and left eye at presentation

was also treated with topical nonsteroidal anti-inflammatory drops of nepafenac, for one month, to hasten recovery. Six weeks after drug discontinuation, best corrected visual acuities improved to $12 / 20$ and $6 / 20$ in the right and left eye, respectively. The SD-OCT showed a marked reduction of the intraretinal fluid, with only small cystic spaces remain- ing, and a decreased retinal thickness (CRT of 371 and 435 $\mu \mathrm{m}$ in the right and left eye, respectively) (Fig. 2). Three months after stopping treatment, visual acuity improved to 20/20 and 16/20 and the SD-OCT showed complete resolution of the cystoid macular edema, with CRT of $288 \mu \mathrm{m}$ in the right eye and $280 \mu \mathrm{m}$ in the left eye, respectively
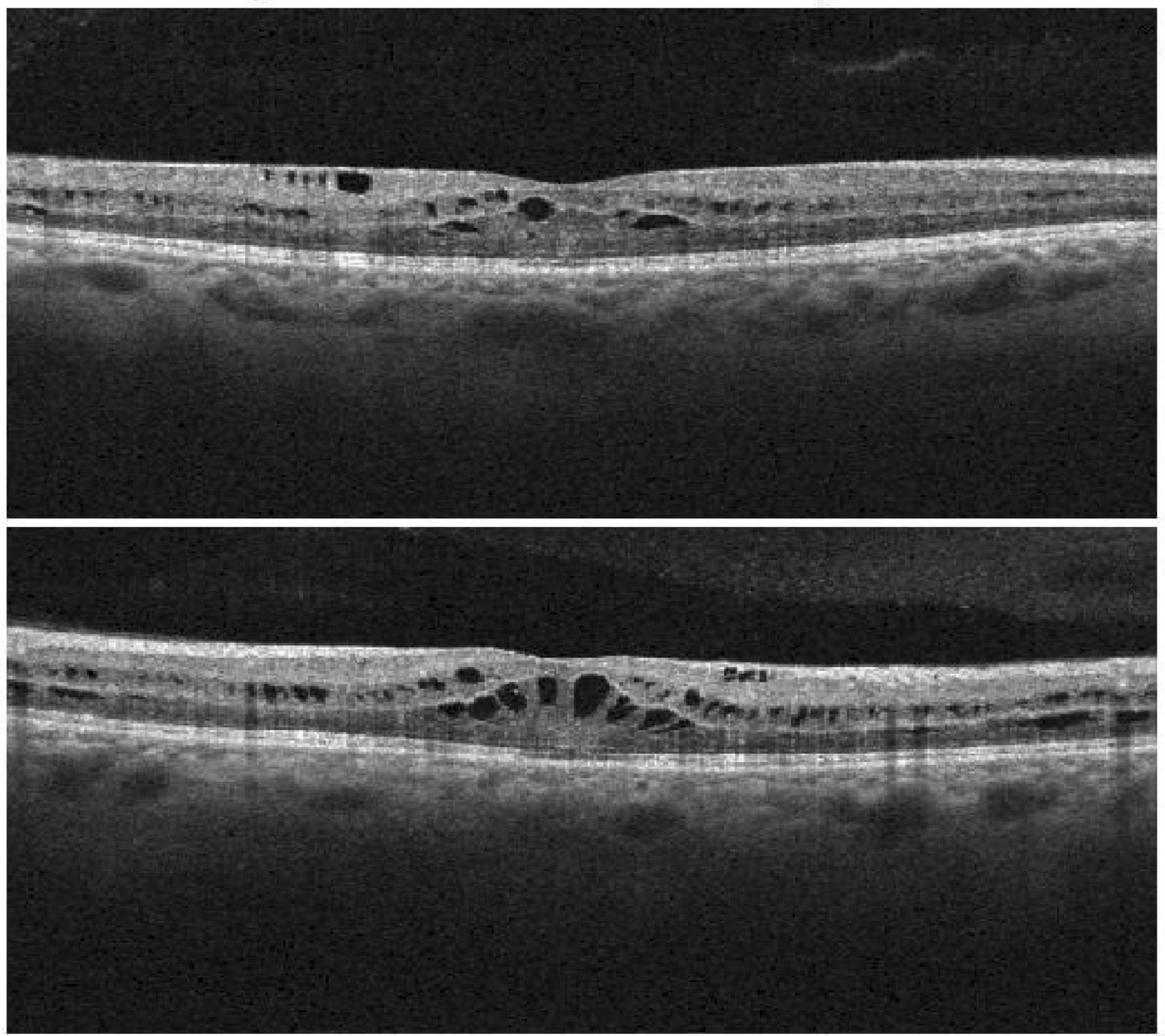

Figure 2 - OCT (right and left eye) six weeks after drug withdrawal with marked improvement of edema 
(Fig. 3). The patient's malignancy was stable under the alternative chemotherapy regimen, with no signs of toxicity or systemic side effects.

\section{DISCUSSION}

Macular edema is caused by fluid accumulation in the retina's extracellular space, leading to abnormal macular thickening. Macular edema can be classified as diffuse or cystoid (when there is evidence of fluid accumulation in the macula in cyst-like spaces). ${ }^{7}$

Taxanes are a class of microtubule stabilizing agents used as chemotherapeutic agents in several malignancies. These agents are known to cause, in very rare instances, a macular edema that is silent on fluorescein angiography (without fluorescein leakage from retinal vessels). ${ }^{8,9}$ The differential diagnosis of cystoid macular edema without (or minimal) fluorescein leakage includes Goldmann-Favre syndrome, niacin maculopathy, juvenile X-linked retinoschisis and some subtypes of retinitis pigmentosa. ${ }^{10}$ Taxane- related macular edema is usually bilateral and the time interval from exposure to clinical presentation can range from a few months to about 2.5 years. ${ }^{8,11}$

The pathophysiology of this taxane-related maculopathy is still unclear. Some authors proposed a mechanism of toxicity to the retinal pigment epithelium (RPE) cells, while others have suggested the role of direct toxicity to the Muller cells, causing swelling. Other possible explanations could be the leakage of molecules smaller than fluorescein (or at a slow leaking rate) not detected by conventional fluorescein angiography. ${ }^{10,12,13}$

Drug discontinuation is the appropriate management of this condition and macular edema is usually reversible upon drug discontinuation. ${ }^{8}$ Visual acuity frequently improves with resolution of macular edema, but the length of treatment and duration of edema can influence visual outcomes. Adjuvant treatment in these cases remains controversial. Use of topical (and sub-tenon or intravitreal) corticosteroids, nonsteroidal anti-inflammatory drugs and carbonic anhydrase
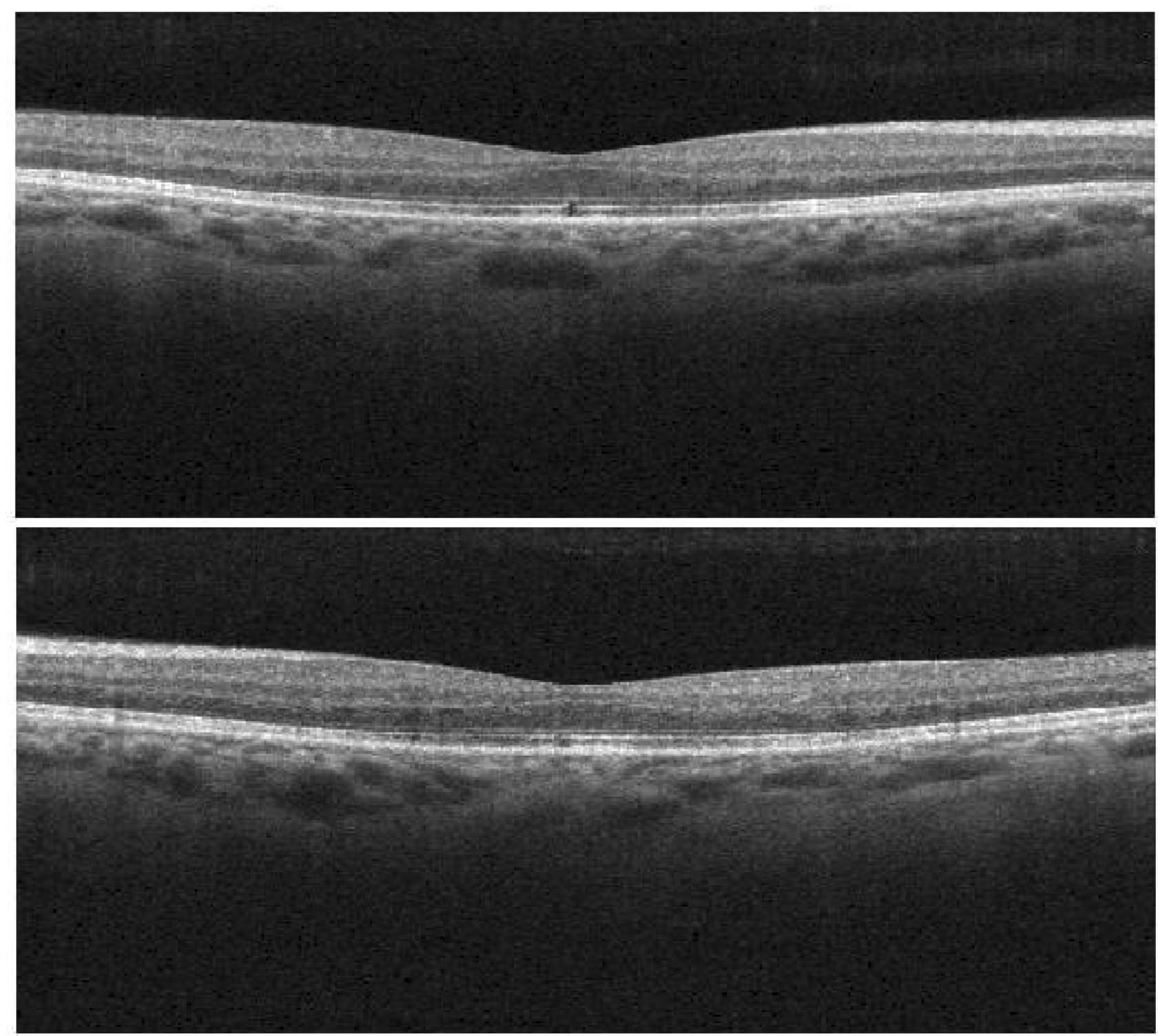

Figure 3 - Normal OCT (right and left eye) three months after drug discontinuation 
inhibitors have been described with little or no efficacy. ${ }^{10,12}$

Taxanes may be associated, in very rare cases, with the development of reversible macular edema. Clinicians, especially oncologists and ophthalmologists, should be aware of this potential side effect in order to better diagnose and treat this condition.

\section{AUTHORS CONTRIBUTION}

SAP: Draft of the paper.

$\mathrm{CV}$ : Analysis and interpretation of the materials.

JM, FS: Critical review and approval of the final version of the paper.

\section{PROTECTION OF HUMANS AND ANIMALS}

The authors declare that the procedures were followed according to the regulations established by the Clinical Research and Ethics Committee and to the 2013 Helsinki Declaration of the World Medical Association.

\section{REFERENCES}

1. Weaver BA. How taxol/paclitaxel kills cancer cells. Mol Biol Cell 2014;25:2677-81.

2. Hoffman RM, Bouvet M. Nanoparticle albumin-bound-paclitaxel: a limited improvement under the current therapeutic paradigm of pancreatic cancer. Expert Opin Pharmacother. 2015;16:943-7.

3. Kim G. nab-Paclitaxel for the treatment of pancreatic cancer. Cancer Manag Res. 2017;9:85-96.

4. Picard M. Management of hypersensitivity reactions to taxanes. Immunol Allergy Clin North Am. 2017;37:679-93.

5. Rivera E, Cianfrocca M. Overview of neuropathy associated with taxanes for the treatment of metastatic breast cancer. Cancer Chemother Pharmacol. 2015;75:659-70.

6. Tanaka Y, Bando H, Hara H, Ito Y, Okamoto Y. Cystoid macular edema induced by nab-paclitaxel. Breast Cancer. 2015;22:324-6.

7. Johnson MW. Etiology and treatment of macular edema. Am J Ophthalmol. 2009;147:11-21 e1.

\section{DATA CONFIDENTIALITY}

The authors declare that they followed the protocols in use at their working center regarding patients' data publication.

\section{PATIENT CONSENT}

Obtained.

\section{COMPETING INTERESTS}

The authors have declared that no competing interests exist.

\section{FUNDING SOURCES}

This research received no specific grant from any funding agency in the public, commercial, or not-for-profit sectors.

8. Freitas-da-Costa P, Brandao E, Braganca T, Falcao-Reis F, Carneiro A. Multimodal imaging in paclitaxel-induced macular edema: the microtubule disfunction. Cutan Ocul Toxicol. 2015;34:347-9.

9. Park E, Goldberg NR, Adams S. Nab-paclitaxel-induced cystoid macular edema in a patient with pre-existing optic neuropathy. Anticancer Drugs. 2016;27:580-4.

10. Chang SY, Tsai SH, Chen LJ, Chan WC. Paclitaxel-induced cystoid macular oedema. Acta Ophthalmol. 2018;96:e649-50.

11. Smith SV, Benz MS, Brown DM. Cystoid macular edema secondary to albumin-bound paclitaxel therapy. Arch Ophthalmol. 2008;126:1605-6.

12. Koo NK, Kim YC. A case of paclitaxel-induced maculopathy treated with methazolamide. Korean J Ophthalmol. 2012;26:394-7.

13. Telander DG, Sarraf D. Cystoid macular edema with docetaxe chemotherapy and the fluid retention syndrome. Semin Ophthalmol. 2007;22:151-3. 